\title{
PEMBELAJARAN MATEMATIKA MELALUI METODE THINKING ALOUD PAIR PROBLEM SOLVING DALAM MENINGKATKAN KEMAMPUAN SISWA KELAS VII-B SMP MUHAMMADIYAH 13 SURABAYA
}

\author{
Farida Hanum ${ }^{1}$, Chusnal Ainy ${ }^{2}$, Endang Suprapti ${ }^{3}$ \\ Program Studi Pendidikan Matematika, FKIP UMSurabaya \\ hanumfarida2806@yahoo.com
}

\begin{abstract}
ABSTRAK
Salah satu masalah dalam pembelajaran matematika di SMP Muhammadiyah 13 adalah karena kemampuan siswa dalam menguasai materi matematika masih rendah dan keaktifan siswa dalam menjawab permasalahan masih rendah sehingga siswa cenderung pasif. Salah satu alternatif metode pembelajaran yang dapat digunakan Thinking Aloud Pair Problem Solving. Penelitian ini bertujuan untuk mendeskripsikan kemampuan siswa, aktivitas siswa, respon siswa kelas VII-B SMP Muhammadiyah 13 dengan menggunakan metode Thinking Aloud Pair Problem Solving, meningkatnya kemampuan siswa dilihat dari hasil belajar siswa. Hasil analisa data kemampuan siswa kelas VII B SMP Muhammadiyah 13 Surabaya dapat ditingkatkan dengan menggunakan metode Thinking Aloud Pair Problem Solving. Rata-rata nilai siswa meningkat dari siklus I dengan rata-rata 69, meningkat sebesar 6\% dari nilai (UTS) semester genap dan dari siklus II meningkat $16 \%$ dari siklus I dengan rata-rata 80 . Hasil analisis aktivitas siswa teliti dalam menyelesaikan masalah dengan memperoleh presentase terbesar, yaitu 20\%. Respon siswa menunjukkan persentase 92,3\% siswa berminat mengikuti pembelajaran matematika.
\end{abstract}

Kata Kunci: kemampuan siswa, thinking aloud pair problem solving

\begin{abstract}
One of the problems in mathematics at SMP Muhammadiyah 13 is due to the ability of the students in mastering mathematic material that is low and the activity of students in answering the problem is still low so that students tend to be passive. One of alternative methods that can be used Thinking Aloud Pair Problem Solving. This study aimed to describe the ability of students, student activities, and student responses class VII-B SMP Muhammadiyah 13 by using Thinking Aloud Pair Problem Solving, increasing the ability of students seen from the results of student learning. The results of the data analysis capabilities of students of class VII B SMP Muhammadiyah 13 Surabaya could be improved by using the method of Thinking Aloud Pair Problem Solving. The average value of the first cycle of students increased by an average of 69, an increase of 6\% of the value (Mid Term Test) and the second semester of the second cycle increased 16\% from the first cycle with an average of 80 . The results of the analysis showed the student activity conscientious in solving problems to obtain the largest percentage, namely 20\%. The students' responses indicated the percentage of $92.3 \%$ who were interested in the study of mathematics.
\end{abstract}

Keywords: Thinking Aloud Pair Problem Solving, The Ability of Students.

\section{PENDAHULUAN}

Matematika berasal dari akar kata mathema artinya pengetahuan, mathanein artinya berpikir atau belajar. Menurut Hamzah dan Muhlisrarini (2013:48) kata matematika diartikan sebagai ilmu yang membahas angka-angka dan 
perhitungannya, membahas masalah-masalah numerik, mengenai kuantitas dan besaran, mempelajari hubungan pola, bentuk dan struktur, sarana berpikir, kumpulan sistem, struktur dan alat. Matematika merupakan salah satu ilmu dasar yang mempunyai peranan penting baik dalam kehidupan sehari-hari maupun dalam pengembangan ilmu dan teknologi. Matematika juga ilmu utama yang mendasari perkembangan teknologi. Matematika sering dipandang sebagai bahasa ilmu, alat komunikasi antara ilmu dan ilmuwan serta merupakan alat analisis data. Dengan demikian matematika sebagai sarana strategis dalam mengembangkan kemampuan dan keterampilan intelektual.

Mengingat pentingnya peranan matematika, berbagai usaha telah dilakukan untuk meningkatkan mutu pendidikan matematika, antara lain dengan penyempurnaan kurikulum dan pengadaan buku paket, akan tetapi masih ada siswa yang menganggap bahwa matematika adalah pelajaran paling sulit dan menakutkan. Hal ini terjadi karena beberapa siswa hanya sekedar menghafal rumus, lalu mengikuti langkah guru dalam menjawab soal, dan bukan menganalisa persoalan yang diberikan. Maka ini akan sangat berpengaruh pada minat siswa dalam mempelajari matematika. Semakin rendah minat siswa untuk mempelajari matematika, menyebabkan semakin rendah pula kemampuan siswa dalam menguasai materi-materi pada pelajaran matematika.

Pernyataan diatas didukung oleh kenyataan di lapangan yaitu di SMP Muhammadiyah 13 yang menunjukkan bahwa kemampuan siswa dalam menguasai materi-materi matematika masih rendah jika dibandingkan dengan mata pelajaran lain. Menurut David (2004:139) Thinking Aloud Pair Problem Solving adalah metode artikulasi-refleksi yang dikembangkan dan diteliti selama bertahun-tahun oleh Whimbey dan Lochhead yang merupakan suatu metode pembelajaran yang mengkombinasikan dari berpikir keras dan teknik mengungkapkan kembali. Berdasarkan uraian di atas, maka dalam rangka meningkatkan kemapuan siswa dan keaktifan belajar siswa, penulis ingin mengadakan penelitian yang berhunbungan dengan masalah tersebut yaitu "Pembelajaran Matematika Melalui Metode Thinking Aloud Pair Problem Solving dalam Meningkatkan Kemampuan Siswa Kelas VII-B SMP Muhammadiyah 13 Surabaya". 
Adapun tujuan penelitian ini adalah:

1. Untuk mendeskripsikan peningkatan kemampuan siswa kelas VII-B SMP Muhammadiyah 13 Surabaya melalui metode pembelajaran Thinking Aloud Pair Problem Solving (TAPPS).

2. Untuk mendeskripsikan aktivitas belajar siswa kelas VII-B SMP Muhammadiyah 13 Surabaya melalui metode pembelajaran Thinking Aloud Pair Problem Solving (TAPPS).

3. Untuk mendeskripsikan respon siswa kelas VII-B SMP Muhammadiyah 13 Surabaya terhadap metode pembelajaran Thinking Aloud Pair Problem Solving (TAPPS).

\section{METODE PENELITIAN}

Penelitian ini termasuk dalam jenis penelitian tindakan kelas (PTK) karena dalam penelitian ini akan dilakukan tindakan-tindakan tertentu untuk memperbaiki proses belajar mengajar di kelas. Sebagai rinci rancangan dan langkah-langkah penelitian tindakan kelas yaitu pertama kegiatan awal dengan mengamati aktivitas siswa dan mengobservasi nilai hasil belajar siswa sebelum pembelajaran melalui penggunaan metode Thinking Aloud Pair Problem. Kedua perencanaan dengan menyusun Rencana Pelaksanaan Pembelajaran (RPP), menyusun lembar kerja siswa (LKS), membuat lembar observasi aktivitas siswa dan aktivitas guru, membuat angket, ketiga pelaksanaan dan observasi yaitu pelaksanaan tindakan ini sesuai dengan RPP yang telah dibuat oleh peneliti dan menggunakan fase yaitu fase 1 menyampaikan tujuan dan memotivasi siswa, fase 2 menyajikan informasi, fase 3 mengorganisasikan siswa dalam kelompok kooperatif, fase 4 membimbing kelompok bekerja dan belajar, fase 5 evaluasi dan fase 6 memberikan penghargaan. Teknik untuk memperoleh data yaitu:

1. Untuk Ketuntasan Belajar

Analisis data untuk hasil belajar siswa secara klasikal

$$
E=\frac{n}{N} \times 100 \% \quad \text { (Asrawi, 2013:32) }
$$

Keterangan:

E : Persentase ketuntasan belajar dikelas

$\mathrm{N}$ : Jumlah siswa keseluruhan

$\mathrm{n}$ : Jumlah siswa yang tuntas belajar 
Analisis data untuk hasil belajar siswa menggunakan tingkat penguasaan

$$
T p=\frac{\text { Skor Aktual }}{\text { Skor Maksimal Ideal }} \times 100 \% \quad \text { (Arikunto, 2009:236) }
$$

Keterangan:

$\mathrm{Tp}$

$$
\text { : Tingkat Penguasaan }
$$

Skor actual

$$
\text { : Jumlah skor yang diperoleh }
$$

Skor maksimal ideal : Skor maksimal yang diharapkan

2. Mencari rata-rata dan varians

$$
\bar{X}=\frac{\sum x}{N} \quad \text { (Arikunto, 2009:264) } \quad \sigma^{2}=\frac{\sum x^{2}-\frac{\left(\sum x\right)^{2}}{N}}{N} \quad \text { (Arikunto, 2009:110) }
$$

Keterangan:

$\bar{X}=$ Nilai rata-rata

$X=$ Data

$N=$ Banyaknya data

$\sigma=$ Simpangan baku

3. Analisis data untuk aktivitas siswa dengan teknik prosentase

$$
T p=\frac{n(A)}{n(A S)} \times 100 \% \quad \text { (Masriyah, 2007) }
$$

Keterangan:

Tp : Prosentase aktivitas siswa

$\mathrm{n}(\mathrm{A}) \quad$ : Jumlah aktivitas yang muncul

$\mathrm{n}(\mathrm{AS})$ : Jumlah aktivitas keseluruhan

4. Analisis data untuk aktivitas guru dalam mengelola pembelajaran dengan metode Thinking Aloud Pair Problem Solving.

Tabel 1. Kriteria Aktivitas Guru dalam Mengelola Pembelajaran dengan TAPPS

\begin{tabular}{|c|c|}
\hline Nilai & Kriteria \\
\hline $0,0<\mathrm{KG}<0,8$ & Tidak Baik \\
\hline $0,8<\mathrm{KG}<1,6$ & Kurang Baik \\
\hline $1,6<\mathrm{KG}<2,4$ & Cukup Baik \\
\hline $2,4<\mathrm{KG}<3,2$ & Baik \\
\hline $3,2<\mathrm{KG}<4,0$ & Sangat Baik \\
\hline
\end{tabular}

Keterangan:

KG: Kemampuan Guru 
Skor dari tiap aspek yang diamati selama beberapa kali pertemuan dirata-rata dengan cara:

$$
\text { skor }=\frac{\text { jumlah skor yang diperoleh guru }}{\text { banyak petemuan }}
$$

(Ariani, 2014:53)

Analisis data untuk mengetahui nilai peningkatan hasil belajar siswa

$$
\text { Peningkataan siswa }=\frac{\bar{x}_{2-\bar{x}_{1}}}{\bar{x}_{1}} \times 100 \%
$$

(Asrawi, 2013:33)

Keterangan:

$x_{1}$ : rata - rata nilai pertama

$x_{2}$ : rata - rata nilai kedua

\section{HASIL PENELITIAN DAN PEMBAHASAN}

Thinking Aloud Pair Problem Solving (TAPPS). Pada penelitian ini terdapat dua jenis data, yaitu data sebelum tindakan dan data setelah ada tindakan. Data sebelum tindakan diperoleh dari hasil ulangan tengah semester (UTS) genap yang didapat dari guru mata pelajaran. Data sesudah tindakan diperoleh dari observasi aktivitas siswa, hasil tes dan angket siswa yang diberikan oleh peneliti selama melakukan penelitian di SMP Muhammadiyah 13 Surabaya.

\section{Data Sebelum Penelitian}

Tabel 2. Rekapitulasi Nilai UTS Genap Kelas VII B

\begin{tabular}{|c|c|c|c|}
\hline \multicolumn{2}{|c|}{ UTS Genap } & \multirow{2}{*}{ Nilai Rata-rata } \\
\cline { 1 - 2 } & Jumlah Siswa & Prosentase & \\
\hline Tuntas Belajar (nilai $\geq 75$ ) & 6 & $23,08 \%$ & 65 \\
\hline Tidak Tuntas Belajar (nilai $<75$ ) & 20 & $76,92 \%$ & \\
\hline Jumlah & 26 & $100 \%$ & 65 \\
\hline
\end{tabular}

\section{Data Setelah Penelitian}

\section{a. Data Siklus I}

\section{1) Nilai Tes 1}

Tabel 3. Rekapitulasi Nilai Tes Siklus 1 Kelas VII B

\begin{tabular}{|c|c|c|c|}
\hline \multicolumn{2}{|c|}{ Tes Siklus I } & \multirow{2}{*}{ Nilai Rata-rata } \\
\hline Tuntas Belajar (nilai $\geq 75$ ) & Jumlah Siswa & Prosentase & 69 \\
\cline { 1 - 2 } Tidak Tuntas Belajar (nilai $<75$ ) & 12 & $46,15 \%$ & \\
\hline Jumlah & 14 & $53,85 \%$ & 69 \\
\hline
\end{tabular}




\section{2) Hasil Observasi Siswa}

Tabel 4. Rekapitulasi Aktivitas Siswa Pada Siklus I

\begin{tabular}{|c|c|c|c|c|c|c|c|}
\hline \multirow{3}{*}{ NO } & \multirow{3}{*}{ Aktivitas } & \multicolumn{6}{|c|}{ Siklus I } \\
\hline & & \multicolumn{3}{|c|}{$\begin{array}{l}\text { Aktivitas Siswa } \\
\text { Pertemuan Ke-1 }\end{array}$} & \multicolumn{3}{|c|}{$\begin{array}{l}\text { Aktivitas Siswa } \\
\text { Pertemuan Ke-2 }\end{array}$} \\
\hline & & Total & Rata2 & $\%$ & Total & Rata2 & $\%$ \\
\hline 1 & $\begin{array}{l}\text { Mendengarkan/memperhatikan } \\
\text { penjelasan guru/teman }\end{array}$ & 79 & 3,03 & 18,9 & 75 & 2,88 & 18 \\
\hline 2 & Mengerjakan materi ajar/LKS & 50 & 1,9 & 12,1 & 50 & 1,9 & 12,1 \\
\hline 3 & $\begin{array}{l}\text { Keterlibatan siswa sebagai problem } \\
\text { solver dan listener }\end{array}$ & 52 & 2 & 12,5 & 52 & 2 & 12,5 \\
\hline 4 & $\begin{array}{l}\text { Bertanya kepada guru apabila ada } \\
\text { kesulitan }\end{array}$ & 11 & 0,4 & 2,6 & 11 & 0,4 & 2,6 \\
\hline 5 & $\begin{array}{l}\text { Siswa teliti dalam menyelesaikan } \\
\text { masalah }\end{array}$ & 77 & 2,9 & 18,5 & 77 & 2,9 & 18,5 \\
\hline 6 & Berdiskusi/bertanya antar siswa & 78 & 3 & 18,8 & 78 & 3 & 18,8 \\
\hline 7 & Menyampaikan ide/pendapat. & 56 & 2,2 & 13,5 & 60 & 2,3 & 14,4 \\
\hline 8 & $\begin{array}{l}\text { Perilaku yang tidak relevan dengan } \\
\text { KBM (mengantuk, tidak } \\
\text { memperhatikan, bercanda, dll) }\end{array}$ & 13 & 0,5 & 3,1 & 13 & 0,5 & 3,1 \\
\hline & Jumlah & 416 & & 100 & 416 & & 100 \\
\hline
\end{tabular}

\section{3) Hasil Observasi Guru}

Tabel 5. Kriteria Aktivitas Guru Pada Siklus I

\begin{tabular}{|l|c|c|c|c|}
\hline \multirow{2}{*}{ Aspek yang diamati } & P-1 & P-2 & Skor & \multirow{2}{*}{ Kriteria } \\
\cline { 2 - 5 } & Nilai & \\
\hline Pendahuluan & $\mathbf{3 , 4}$ & $\mathbf{3 , 4}$ & $\mathbf{3 , 4}$ & Sangat baik \\
\hline Rata-rata (1) & $\mathbf{3 , 4}$ & $\mathbf{3 , 4}$ & $\mathbf{3 , 4}$ & Sangat baik \\
\hline Inti & $\mathbf{3 , 0}$ & $\mathbf{3 , 0}$ & $\mathbf{3 , 0}$ & Baik \\
\hline Rata-rata (2) & $\mathbf{3 , 0}$ & $\mathbf{3 , 0}$ & $\mathbf{3 , 0}$ & Baik \\
\hline Penutup & $\mathbf{3 , 0}$ & $\mathbf{3 , 0}$ & $\mathbf{3 , 0}$ & Baik \\
\hline Rata-rata (3) & $\mathbf{3 , 3}$ & $\mathbf{3 , 3}$ & $\mathbf{3 , 3}$ & Sangat baik \\
\hline Pengelolaan waktu (4)
\end{tabular}

\section{b. Data Siklus II}

\section{1) Nilai Tes 2}

Tabel 6. Rekapitulasi Nilai Tes Siklus II Kelas VII B

\begin{tabular}{|l|c|c|c|}
\hline \multicolumn{2}{|c|}{ Tes Siklus II } & \multirow{2}{*}{ Nilai Rata-rata } \\
\cline { 1 - 2 } & Jumlah Siswa & Prosentase & \\
\hline Tuntas Belajar (nilai $\geq 75$ ) & 22 & $84,62 \%$ & 80 \\
\hline Tidak Tuntas Belajar (nilai $<75$ ) & 4 & $15,38 \%$ & \\
\hline Jumlah & 26 & $100 \%$ & 80 \\
\hline
\end{tabular}




\section{2) Hasil Observasi Siswa}

Tabel 7. Rekapitulasi Aktivitas Siswa Pada Siklus II

\begin{tabular}{|c|c|c|c|c|c|c|c|}
\hline \multirow{3}{*}{ NO } & \multirow{3}{*}{ Aktivitas } & \multicolumn{6}{|c|}{ Siklus II } \\
\hline & & \multicolumn{3}{|c|}{$\begin{array}{l}\text { Aktivitas Siswa } \\
\text { Pertemuan Ke-4 }\end{array}$} & \multicolumn{3}{|c|}{$\begin{array}{l}\text { Aktivitas Siswa } \\
\text { Pertemuan Ke-5 }\end{array}$} \\
\hline & & Total & Rata2 & $\%$ & Total & Rata2 & $\%$ \\
\hline 1 & $\begin{array}{l}\text { Mendengarkan/memperhatikan } \\
\text { penjelasan guru/teman. }\end{array}$ & 73 & 2,8 & 17,6 & 67 & 4,2 & 16,1 \\
\hline 2 & Mengerjakan materi ajar/LKS & 52 & 2 & 12,5 & 52 & 2 & 12,5 \\
\hline 3 & $\begin{array}{l}\text { Keterlibatan siswa sebagai } \\
\text { problem solver dan listener }\end{array}$ & 52 & 2 & 12,5 & 52 & 2 & 12,5 \\
\hline 4 & $\begin{array}{l}\text { Bertanya kepada guru apabila ada } \\
\text { kesulitan }\end{array}$ & 10 & 0,4 & 2,4 & 8 & 0,3 & 1,9 \\
\hline 5 & $\begin{array}{l}\text { Siswa teliti dalam menyelesaikan } \\
\text { masalah }\end{array}$ & 80 & 3,1 & 19,2 & 83 & 3,2 & 20 \\
\hline 6 & Berdiskusi/bertanya antar siswa & 79 & 3 & 19 & 80 & 3,1 & 19,2 \\
\hline 7 & Menyampaikan ide/pendapat. & 62 & 2,4 & 14,9 & 68 & 2,6 & 16,4 \\
\hline 8 & $\begin{array}{l}\text { Perilaku yang tidak relevan } \\
\text { dengan KBM (mengantuk, tidak } \\
\text { memperhatikan, bercanda, dll) }\end{array}$ & 8 & 0,3 & 1,9 & 6 & 0,23 & 1,4 \\
\hline & Jumlah & 416 & & 100 & 416 & & 100 \\
\hline
\end{tabular}

\section{3) Hasil Observasi Guru}

Tabel 8 Kriteria Aktivitas Guru Pada Siklus II

\begin{tabular}{|l|c|c|c|c|}
\hline \multicolumn{1}{|c|}{ Aspek yang diamati } & P-4 & P-5 & \multirow{2}{*}{ Skor } & \multirow{2}{*}{ Kriteria } \\
\cline { 2 - 5 } & \multicolumn{5}{|c|}{ Nilai } & \\
\hline Pendahuluan & $\mathbf{3 , 4}$ & $\mathbf{3 , 6}$ & $\mathbf{3 , 5}$ & Sangat baik \\
\hline Rata-rata (1) & $\mathbf{3 , 7}$ & $\mathbf{3 , 7}$ & $\mathbf{3 , 7}$ & Sangat baik \\
\hline Inti & $\mathbf{3 , 0}$ & $\mathbf{3 , 0}$ & $\mathbf{3 , 0}$ & Baik \\
\hline Rata-rata (2) & $\mathbf{3 , 0}$ & $\mathbf{4 , 0}$ & $\mathbf{3 , 5}$ & Sangat baik \\
\hline Penutup & & & \\
\hline Rata-rata (3) & $\mathbf{3 , 3}$ & $\mathbf{3 , 7}$ & $\mathbf{3 , 5}$ & Sangat baik \\
\hline Pengelolaan waktu (4) & $\mathbf{3 , 4}$ & $\mathbf{3 , 6}$ & $\mathbf{3 , 5}$ & Sangat baik \\
\hline Suasana kelas
\end{tabular}




\section{Hasil Kuesioner Siswa}

Tabel 9. Persentase Hasil Kuesioner Kelas VII B

\begin{tabular}{|c|c|c|c|}
\hline \multirow{2}{*}{ No } & \multirow{2}{*}{ Respon Siswa } & \multicolumn{2}{|c|}{ Jenis Respon } \\
\hline & & Ya & Tidak \\
\hline 1 & $\begin{array}{l}\text { Apakah metode pembelajaran yang telah dilakukan } \\
\text { membuat saya lebih aktif dalam proses pembelajaran } \\
\text { dikelas. }\end{array}$ & $\begin{array}{c}22 \\
(84,6 \%)\end{array}$ & $\begin{array}{c}4 \\
(15,4 \%)\end{array}$ \\
\hline 2 & $\begin{array}{l}\text { Metode pembelajaran yang telah dilakukan ini membuat } \\
\text { saya faham dengan materi pelajaran yang disampaikan. }\end{array}$ & $\begin{array}{c}20 \\
(76,92 \%)\end{array}$ & $\begin{array}{c}6 \\
(23,08 \%)\end{array}$ \\
\hline 3 & $\begin{array}{l}\text { Apakah metode pembelajaran yang telah dilakukan dapat } \\
\text { diterapkan pada pokok bahasan segiempat. }\end{array}$ & $\begin{array}{c}23 \\
(88,46 \%)\end{array}$ & $\begin{array}{c}3 \\
(11,54 \%)\end{array}$ \\
\hline 4 & $\begin{array}{l}\text { Apakah anda merasa nyaman (senang) belajar matematika } \\
\text { selama metode yang telah dilakukan ini. }\end{array}$ & $\begin{array}{c}22 \\
(84,6 \%)\end{array}$ & $\begin{array}{c}4 \\
(15,4 \%)\end{array}$ \\
\hline 5 & $\begin{array}{l}\text { Apakah anda berminat mengikuti pembelajaran } \\
\text { matematika seperti metode yang telah dilakukan ini. }\end{array}$ & $\begin{array}{c}24 \\
(92,3 \%)\end{array}$ & $\begin{array}{c}2 \\
(7,7 \%)\end{array}$ \\
\hline 6. & $\begin{array}{l}\text { Metode pembelajaran yang dipakai ini membantu saya } \\
\text { lebih termotivasi untuk mendengarkan materi } \\
\text { pelajarannya. }\end{array}$ & $\begin{array}{c}21 \\
(80,8 \%)\end{array}$ & $\begin{array}{c}5 \\
(19,2 \%)\end{array}$ \\
\hline 7. & $\begin{array}{l}\text { Apakah metode pembelajaran ini perlu digunakan sebagai } \\
\text { variasi dalam perubahan suasana belajar dikelas. }\end{array}$ & $\begin{array}{c}23 \\
(88,46 \%)\end{array}$ & $\begin{array}{c}3 \\
(11,54 \%)\end{array}$ \\
\hline 8. & $\begin{array}{l}\text { Apakah LKS yang digunakan menarik pada materi di } \\
\text { pembelajaran ini? }\end{array}$ & $\begin{array}{c}21 \\
(80,8 \%)\end{array}$ & $\begin{array}{c}5 \\
(19,2 \%)\end{array}$ \\
\hline
\end{tabular}

\section{Pembahasan}

\section{Siklus 1}

Sebelum melakukan penelitian, peneliti melakukan sebuah observasi awal di SMP Muhammadiyah 13 Surabaya untuk mengetahui bagaimana kegiatan proses pembelajaran yang dilakukan oleh guru matematika selama ini dan mengetahui apa saja yang mempengaruhi rendahnya kemampuan siswa dalam pembelajaran matematika didalam kelas. Selanjutnya peneliti menyiapkan perangkat pembelajaran, instrument penilaian dan angket respon siswa. Perangkat pembelajaran meliputi rencana pelaksanaan pembelajaran (RPP) yang terdiri 6 kali pertemuan dan 1 RPP terdiri 3 kali pertemuan dan lembar kerja siswa (LKS) ada 6 masalah dalam kehidupan sehari-hari tentang keliling maupun luas persegi panjang, persegi, trapesium, jajargenjang, belah ketupat dan layang-layang,sedangkan instrument penilaian yang digunakan adalah lembar aktivitas siswa, lembar aktivitas guru, dan soal tes yang terdiri dari 6 soal, sedangkan angket respon siswa yaitu lembar respon siswa tentang pembelajaran dengan menggunakan metode 
Thinking Aloud Pair Problem Solving. Angket respon siswa tersebut terdiri dari 8 pertanyaan dengan pilihan jawaban ya atau tidak.

Pelaksanaan dalam siklus I dilaksanakan dalam 3 pertemuan yaitu pertemuan pertama pada hari Jum'at tanggal 13 Mei 2016, pertemuan kedua pada hari Sabtu tanggal 14 Mei 2016 dan pertemuan ketiga pada hari Rabu tanggal 18 Mei 2016. Setiap pertemuan dilaksanakan dalam 2 jam pelajaran durasi 1 jam pelajaran 40 menit.

Pada pertemuan pertama guru menyiapkan lembar kerja siswa (LKS), didalam LKS terdapat 6 masalah dalam kehidupan sehari-hari tentang keliling persegi panjang, persegi dan trapesium. Selanjutnya guru membagi siswa dalam 13 kelompok dengan jumlah perkelompok adalah 2 siswa dan masing-masing diberikan lembar kerja siswa yang diselesaikan dengan pasangannya. Pasangan tersebut terdiri dari problem solver dan listener. Siswa yang yang berperan sebagai problem solver memiliki tugas untuk menjelaskan tahap demi tahap dalam menyelesaikan masalah, sedangkan siswa yang menjadi listener memiliki tugas untuk memahami setiap langkah yang dilakukan problem solver. Sebagai listener harus memeriksa dan menganalisa kembali penjelasan yang disampaikan oleh problem solver dalam menyelesaikan permasalahan dalam mengisi LKS, selain itu juga dapat mengajukan pertanyaan. Selanjutnya setelah seluruh kelompok mengerjakan LKS, beberapa kelompok membahas hasil diskusinya di depan kelas sedangkan kelompok lain mengamati dan memberikan tanggapan terhadap hasil kerja temannya sedangkan guru memberi penguatan serta mengevaluasi apabila terdapat kesalahan.

Pada pertemuan kedua hampir sama dengan pertemuan pertama yaitu guru menyiapkan lembar kerja siswa (LKS), didalam LKS terdapat 6 masalah dalam kehidupan sehari-hari tentang luas persegi panjang, persegi dan trapesium. Selanjutnya guru membagi siswa dalam 13 kelompok dengan jumlah perkelompok adalah 2 siswa dan masing-masing diberikan lembar kerja siswa yang diselesaikan dengan pasangannya. Pasangan tersebut terdiri dari problem solver dan listener. Siswa yang yang berperan sebagai problem solver memiliki tugas untuk menjelaskan tahap demi tahap dalam menyelesaikan masalah, sedangkan siswa yang menjadi listener memiliki tugas untuk memahami setiap langkah yang 
dilakukan problem solver. Sebagai listener harus memeriksa dan menganalisa kembali penjelasan yang disampaikan oleh problem solver dalam menyelesaikan permasalahan dalam mengisi LKS, selain itu juga dapat mengajukan pertanyaan. Selanjutnya setelah seluruh kelompok mengerjakan LKS, beberapa kelompok membahas hasil diskusinya di depan kelas sedangkan kelompok lain mengamati dan memberikan tanggapan terhadap hasil kerja temannya sedangkan guru memberi penguatan serta mengevaluasi apabila terdapat kesalahan.

Pada pertemuan ketiga guru memberikan soal tes untuk mengukur kemampuan siswa setelah menerapkan metode Thinking Aloud Pair Problem Solving.

Observasi dalam penelitian ini dilakukan oleh 3 pengamat, yakni peneliti sendiri dan 2 pengamat adalah teman sejawat peneliti sebagai pengamat kedua dan pengamat ketiga. Pada pertemuan pertama, siswa sudah terlihat cukup aktif dalam melakukan pembelajaran. Hanya saja masih banyak siswa yang belum antusias dalam mengikuti langkah-langkah pembelajaran. Hal ini dikarenakan beberapa siswa yang lebih mengerti masih dominan dalam menyelesaikan masalah didalam LKS sedangkan siswa yang pasif didalam kelas masih sulit mengerti dalam mengerjakan LKS tersebut. Dan siswa masih banyak membutuhkan arahan guru dalam melakukan peran sebagai problem solver dan listener, siswa masih ragu dalam mengungkapkan pendapat mereka sendiri sehingga masih banyak yang terlihat pasif didalam kelas, masih banyak siswa yang hanya mendengarkan/ memperhatikan guru atau teman saja sehingga masih terlihat agak pasif juga dan banyak siswa dari beberapa kelompok yang menunjukkan perilaku yang tidak relevan dalam kegiatan belajar mengajar.

Pada pertemuan kedua, aktivitas siswa sudah cukup aktif. Siswa-siswa yang berada dalam kelompok mulai yang menjadi peran problem solver maupun listener mereka sudah berani menyampaikan pendapatnya karena ada kenaikan persentase dari pertemuan pertama, walaupun siswa masih membutuhkan arahan guru dalam melakukan peran sebagai problem solver dan listener. Masih sama pada pertemuan pertama, banyak siswa yang hanya mendengarkan/memperhatikan guru atau teman saja sehingga masih terlihat agak pasif juga dan banyak siswa dari beberapa 
kelompok yang menunjukkan perilaku yang tidak relevan dalam kegiatan belajar mengajar.

Pada siklus I terdapat 18\% mendengarkan/memperhatikan penjelasan guru/teman, 12,1\% mengerjakan materi ajar/LKS, 12,5\% keterlibatan siswa sebagai problem solver dan listener, 2,6\% bertanya kepada guru apabila ada kesulitan, 18,5\% teliti dalam menyelesaikan masalah, 18,8\% berdiskusi/bertanya antar siswa, 14,4\% siswa menyampaikan ide/pendapat dan 3,1\% perilaku yang tidak relevan dengan KBM (mengantuk, tidak memperhatikan, bercanda, dll). Dari butir nomor 2,3,5,6,7 total persentase yang didapat 76,3\% dan bisa dikatakan pada siklus I aktivitas siswa masih belum mencapai indikator keberhasilannya karena indikator keberhasilan belum mencapai $80 \%$, sehingga pada siklus II pengamatan aktivitas siswa tetap dilakukan dengan harapan siswa lebih aktif dibandingkan siklus I dan aktivitas siswa bisa mencapai 80\% dari indikator keberhasilannya.

Dalam hasil tes evaluasi belajar siklus I, hanya terdapat 12 siswa atau 46,15\% dari seluruh siswa kelas VII B sudah tuntas belajar, sedangkan 14 siswa atau 53,85\% dari seluruh siswa kelas VII B belum tuntas belajar. Nilai rata-rata diketahui mengalami peningkatan dari sebelum diberi tindakan yaitu 65 dan setelah diberi tindakan pada siklus I rata-rata menjadi 69. Sehingga kemampuan siswa mengalami peningkatan sebanyak 6\%. Ini menunjukkan bahwa adanya peningkatan kemampuan siswa dari sebelum diberikan tindakan ke siklus I meskipun nilai rata-rata siswa belum mencapai Kriteria Ketuntasan Minimal (KKM) yang ditentukan SMP Muhammadiyah 13 Surabaya yaitu $\geq 75$. Maka penelitian dilanjutkan ke siklus II, dengan harapan kemampuan siswa dapat meningkat.

\section{Siklus II}

Dalam tahap perencanaan siklus II peneliti mengkonsultasikan perangkat pembelajaran maupun instrumen penilaiaan kepada guru agar proses pembelajaran bisa lebih baik. Peneliti bersama guru bekerja sama untuk membuat siswa lebih baik dari siklus I, dari aktivitas siswa dikelas pada saat pembelajaran dengan metode Thinking Aloud Pair Problem Solving. 
Pelaksanaan dalam siklus II dilaksanakan dalam 3 pertemuan yaitu pertemuan keempat pada hari Kamis tanggal 19 Mei 2016, pertemuan kelima pada hari Jum'at tanggal 20 Mei 2016 dan pertemuan keenam pada hari Sabtu tanggal 21 Mei 2016. Setiap pertemuan dilaksanakan dalam 2 jam pelajaran durasi 1 jam pelajaran 40 menit.

Pada pertemuan keempat guru menyiapkan lembar kerja siswa (LKS), didalam LKS terdapat 6 masalah dalam kehidupan sehari-hari tentang keliling jajargenjang, belah ketupat dan layang-layang. Selanjutnya guru membagi siswa dalam 13 kelompok dengan jumlah perkelompok adalah 2 siswa dan masingmasing diberikan lembar kerja siswa yang diselesaikan dengan pasangannya. Pasangan tersebut terdiri dari problem solver dan listener. Siswa yang yang berperan sebagai problem solver memiliki tugas untuk menjelaskan tahap demi tahap dalam menyelesaikan masalah, sedangkan siswa yang menjadi listener memiliki tugas untuk memahami setiap langkah yang dilakukan problem solver. Sebagai listener harus memeriksa dan menganalisa kembali penjelasan yang disampaikan oleh problem solver dalam menyelesaikan permasalahan dalam mengisi LKS, selain itu juga dapat mengajukan pertanyaan. Selanjutnya setelah seluruh kelompok mengerjakan LKS, beberapa kelompok membahas hasil diskusinya di depan kelas sedangkan kelompok lain mengamati dan memberikan tanggapan terhadap hasil kerja temannya sedangkan guru memberi penguatan serta mengevaluasi apabila terdapat kesalahan.

Pada pertemuan kelima hampir sama dengan pertemuan keempat yaitu guru menyiapkan lembar kerja siswa (LKS), didalam LKS terdapat 6 masalah dalam kehidupan sehari-hari tentang luas jajargenjang, belah ketupat dan layang-layang. Selanjutnya guru membagi siswa dalam 13 kelompok dengan jumlah perkelompok adalah 2 siswa dan masing-masing diberikan lembar kerja siswa yang diselesaikan dengan pasangannya. Pasangan tersebut terdiri dari problem solver dan listener. Siswa yang yang berperan sebagai problem solver memiliki tugas untuk menjelaskan tahap demi tahap dalam menyelesaikan masalah, sedangkan siswa yang menjadi listener memiliki tugas untuk memahami setiap langkah yang dilakukan problem solver. Sebagai listener harus memeriksa dan menganalisa kembali penjelasan yang disampaikan oleh problem solver dalam menyelesaikan 
permasalahan dalam mengisi LKS, selain itu juga dapat mengajukan pertanyaan. Selanjutnya setelah seluruh kelompok mengerjakan LKS, beberapa kelompok membahas hasil diskusinya di depan kelas sedangkan kelompok lain mengamati dan memberikan tanggapan terhadap hasil kerja temannya sedangkan guru memberi penguatan serta mengevaluasi apabila terdapat kesalahan.

Pada pertemuan keenam guru memberikan soal tes untuk mengukur kemampuan siswa setelah menerapkan metode Thinking Aloud Pair Problem Solving.

Observasi dalam penelitian ini dilakukan oleh 3 pengamat, yakni peneliti sendiri dan 2 pengamat adalah teman sejawat peneliti sebagai pengamat kedua dan pengamat ketiga. Pada pertemuan keempat, siswa sudah terlihat aktif dalam melakukan pembelajaran, karena mengalami peningkatan aktivitas dari siklus I. Siswa sudah mulai antusias dalam mengikuti langkah-langkah pembelajaran. Mulai dari mengerjakan LKS, keterlibatan siswa menjadi problem solver dan listener lebih aktif didalam kelompk, siswa lebih teliti dalam menyelesaikan masalah di dalam LKS, siswa lebih aktif berdiskusi atau bertanya antar siswa dan siswa lebih berani menyampaikan pendapat mereka. Hal ini dikarenakan berkurangnya aktivitas siswa yang hanya mendengarkan/memperhatikan penjelasan guru atau teman, siswa lebih berupaya sendiri dalam menyelesaikan permasalahan didalam LKS sehingga berkurangnya aktivitas siswa bertanya kepada guru apabila ada kesulitan dan berkurangnya aktivitas siswa dari beberapa kelompok yang menunjukkan perilaku yang tidak relevan dalam kegiatan belajar mengajar.

Pada pertemuan kelima, aktivitas siswa sudah lebih aktif. Siswa-siswa yang berada dalam kelompok mulai yang menjadi peran problem solver maupun listener mereka sudah berani menyampaikan pendapatnya karena ada kenaikan persentase dari pertemuan keempat. Mulai dari mengerjakan LKS, keterlibatan siswa menjadi problem solver dan listener lebih aktif didalam kelompk, siswa lebih teliti dalam menyelesaikan masalah di dalam LKS, siswa lebih aktif berdiskusi atau bertanya antar siswa dan siswa lebih berani menyampaikan pendapat mereka. Hal ini dikarenakan aktivitas siswa pada pertemuan kelima ini lebih meningkat dibandingkan aktivitas pertemuan keempat, berkurangnya aktivitas siswa yang hanya mendengarkan/memperhatikan penjelasan guru atau teman, siswa lebih 
berupaya sendiri dalam menyelesaikan permasalahan didalam LKS sehingga berkurangnya aktivitas siswa bertanya kepada guru apabila ada kesulitan dan berkurangnya aktivitas siswa dari beberapa kelompok yang menunjukkan perilaku yang tidak relevan dalam kegiatan belajar mengajar.

Pada siklus II terdapat 16,1\% mendengarkan/memperhatikan penjelasan guru/teman, 12,5\% mengerjakan materi ajar/LKS, 12,5\% keterlibatan siswa sebagai problem solver dan listener, 1,9\% bertanya kepada guru apabila ada kesulitan, 20\% teliti dalam menyelesaikan masalah, 19,2\% berdiskusi/bertanya antar siswa, 16,4\% siswa menyampaikan ide/pendapat dan 1,4\% perilaku yang tidak relevan dengan KBM (mengantuk, tidak memperhatikan, bercanda, dll). Dari butir nomor 2, 3, 5, 6, 7 total persentase yang didapat 80,6\% dan bisa dikatakan pada siklus II aktivitas siswa sudah mencapai indikator keberhasilannya karena indikator keberhasilan sudah mencapai lebih $80 \%$.

Sebelum peneliti melakukan penelitian, telah didapatkan data sebelum tindakan yaitu data rekapitulasi nilai Ujian Tengah Semester (UTS) kelas VII B yang didapat dari hasil pembelajaran oleh guru dengan menggunakan metode pembelajaran yang biasa digunakan guru mengajar. Data tersebut digunakan sebagai alat ukur keberhasilan pada penelitian ini. Data sesudah tindakan terdiri dari siklus I dan siklus II yaitu nilai siswa setelah tindakan, observasi aktivitas siswa, dan respon siswa terhadap metode pembelajaran Thinking Aloud Pair Problem Solving.

Dalam hasil tes evaluasi belajar siklus II, terdapat 22 siswa atau $84,62 \%$ dari seluruh siswa kelas VII B sudah tuntas belajarnya, sedangkan 4 siswa atau 15,38\% dari seluruh siswa kelas VII B belum tuntas belajarnya. Nilai rata-rata diketahui mengalami peningkatan dari siklus I yaitu 69 dan pada siklus II menjadi 80. Sehingga kemampuan siswa mengalami peningkatan sebanyak $16 \%$. Ini menunjukkan bahwa adanya peningkatan kemampuan siswa dari siklus I ke siklus II sedangkan dari sebelum tindakan dan sesudah tindakan hingga siklus II yaitu sebesar 22\% dan nilai rata-rata siswa sudah mencapai KKM (Kriteria Ketuntasan Minimal) yaitu $\geq 75$. 
Berdasarkan Tabel 9, hasil kuesioner dari 26 siswa kelas VII B SMP Muhammadiyah 13 Surabaya dengan 8 pertanyaan adalah:

1) $84,6 \%$ pembelajaran matematika dengan metode Thinking Aloud Pair Problem Solving membuat siswa lebih aktif dalam proses pembelajaran dikelas dan siswa merasa nyaman (senang) belajar matematika dengan metode Thinking Aloud Pair Problem Solving.

2) 76,92\% pembelajaran dengan metode Thinking Aloud Pair Problem Solving yang dilakukan membuat siswa faham dengan materi pelajaran yang disampaikan.

3) $88,46 \%$ pembelajaran dengan metode Thinking Aloud Pair Problem Solving dapat diterapkan pada pokok bahasan segiempat dan metode Thinking Aloud Pair Problem Solving perlu digunakan sebagai variasi dalam perubahan suasana belajar dikelas.

4) 80,8\% pembelajaran dengan metode Thinking Aloud Pair Problem Solving ini membantu siswa lebih termotivasi untuk mendengarkan materi pelajarannya dan LKS yang digunakan pada metode Thinking Aloud Pair Problem Solving pada materi segiempat ini sangat menarik.

5) $92,3 \%$ siswa berminat mengikuti pembelajaran matematika dengan metode Thinking Aloud Pair Problem Solving.

Secara kesuluruhan dapat disimpulkan bahwa siswa lebih aktif dalam proses pembelajaran dikelas, siswa (nyaman) senang menggunakan metode Thinking Aloud Pair Problem Solving saat guru mengajar, siswa berminat mengikuti pembelajaran matematika dengan menggunakan metode Thinking Aloud Pair Problem Solving, siswa lebih faham terhadap materi yang disampaikan dengan menggunakan metode Thinking Aloud Pair Problem Solving, siswa lebih termotivasi untuk mendengarkan materi pelajaran dengan metode Thinking Aloud Pair Problem Solving. Siswa setuju metode Thinking Aloud Pair Problem Solving dapat diterapkan pada pokok bahasan segiempat dan dapat digunakan sebagai variasi dalam perubahan suasana belajar dikelas. 


\section{SIMPULAN}

Berdasarkan hasil analisis, maka dapat disimpulkan sebagai berikut.

1. Kemampuan siswa kelas VII B SMP Muhammadiyah 13 Surabaya dapat ditingkatkan melalui metode Thinking Aloud Pair Problem Solving (TAPPS). Terlihat dari nilai rata-rata awal yang diambil dari nilai UTS Genap adalah 65 meningkat menjadi 69 pada siklus I atau meningkat sebesar 6\%. Dari siklus I ke siklus II rata-rata nilai kelas VII B meningkat menjadi 80 atau meningkat sebesar 16\%. Dengan demikian, metode Thinking Aloud Pair Problem Solving (TAPPS) dalam pembelajaran matematika dapat meningkatkan kemampuan siswa kelas VII B SMP Muhammadiyah 13 Surabaya.

2. Tindakan pada penelitian ini juga dapat meningkatkan aktivitas siswa dengan mengoptimalkan peran guru dan siswa. Pada siklus I siswa yang memperoleh presentase sebesar 76,3\%. Pada siklus II aktivitas siswa meningkat sebanyak 4,3\% dari nilai aktivitas siswa pada siklus I sehingga presentase aktivitas siswa pada siklus II menjadi 80,6\% dan hal ini bisa dikatakan bahwa aktivitas siswa pada siklus II sudah memenuhi indikator keberhasilan pada penelitian ini.

3. Respon siswa terhadap proses belajar mengajar menggunakan metode Thinking Aloud Pair Problem Solving sangat baik. 84,6\% pembelajaran matematika dengan metode Thinking Aloud Pair Problem Solving membuat siswa lebih aktif dalam proses pembelajaran dikelas dan siswa merasa nyaman (senang) belajar matematika dengan metode Thinking Aloud Pair Problem Solving. 76,92\% pembelajaran dengan metode Thinking Aloud Pair Problem Solving yang dilakukan membuat siswa faham dengan materi pelajaran yang disampaikan. 88,46\% pembelajaran dengan metode Thinking Aloud Pair Problem Solving dapat diterapkan pada pokok bahasan segiempat dan perlu digunakan sebagai variasi dalam perubahan suasana belajar dikelas. 880,8\% pembelajaran dengan metode Thinking Aloud Pair Problem Solving ini membantu siswa lebih termotivasi untuk mendengarkan materi pelajarannya dan LKS yang digunakan pada metode Thinking Aloud Pair Problem Solving pada materi segiempat ini sangat menarik. 92,3\% siswa berminat mengikuti 
pembelajaran matematika dengan metode Thinking Aloud Pair Problem Solving.

\section{DAFTAR PUSTAKA}

Arikunto, Suharsimi. 2009. Dasar-Dasar Evaluasi Pendidikan. Jakarta: Bumi Aksara.

Ariani, Willis. 2014. Efektivitas Pembelajaran Matematika Dengan Model Pembelajaran Reciprocal Teaching Pada Siswa Kelas VII Di SMP Muhammadiyah 10 Surabaya. Skripsi. Surabaya: UM Surabaya Tidak Dipublikasikan.

Asrawi, 2013. Meningkatkan Kemampuan Siswa Kelas IV Pada Operasi Hitung Bilangan Bulat Melalui Media Domat Di SD Integral Luqman Al Hakim Sumenep. Skripsi. Surabaya: UM Surabaya Tidak Dipublikasikan.

David, Jonassen. H, 2004. Learning To Solve Problems An Instructional Design Guide. San Fransisco.

Hamzah, A. \& Mushlisrarini. 2013. Perencanaan Dan Strategi Pembelajaran Matematika. Jakarta: PT RajaGrafindo Persada.

Masriyah. 2007. Modul 9 Penyusunan Non Tes. Surabaya: Universitas Negeri Surabaya 